Volume 1 No. 1

Februari 2020

e-ISSN : 2721-9062

Website:

jurnal.umj.ac.id/index.php/JMMB

Email : jmmb.febumj@gmail.com jmmb@umj.ac.id

\title{
RETURN ON ASSET PERUSAHAAN SUB SEKTOR TELEKOMUNIKASI DAN FAKTOR YANG MEMPENGARUHINYA
}

\author{
Zulfikar Ramadhan ${ }^{1, *}$, Ibnu Harfain ${ }^{2 *}$ \\ ${ }^{1}$ 1Manajemen, Fakultas Ekonomi dan Bisnis, Universitas Muhammadiyah Jakarta, Jl. KH. Ahmad Dahlan, \\ Jakarta, 15419 \\ ${ }^{2} 1$ Manajemen, Fakultas Ekonomi dan Bisnis, Universitas Muhammadiyah Jakarta, Jl. KH. Ahmad Dahlan, \\ Jakarta, 15419 \\ *zulfikar.ramadhan@umj.ac.id \\ *ibnu.harfain@yahoo.com
}

Diterima: 4 Februari 2020

Direvisi: 9 Februari 2020

Disetujui: 12 Februari 2020

DOI : 10.24853/jmmb.1.1.17-24

\begin{abstract}
ABSTRAK
Penelitian ini bertujuan untuk mengetahui pengaruh current ratio, debt to asset ratio, dan total asset turn over terhadap return on asset perusahaan Sub Sektor Telekomunikasi yang terdaftar di Bursa Efek Indonesia periode 2013-2017. Data yang digunakan adalah data sekunder berupa laporan keuangan yang di publikasikan oleh Bursa Efek Indonesiamelalui situs www.idx.co.id. Sampel dalam penelitian ini adalah 4 dari 6 perusahaan. Teknik pengambilan sampel dengan purposive sampling. Metode analisis yang digunakan adalah penentuan model estimasi, uji asumsi klasik, persamaan regresi linear berganda, uji hipotesis. Hasil penelitian menunjukan bahwa current ratio dan total asset turn over berpengaruh positif dan signifikan terhadap return on asset, sedangkan debt to asset ratio berpengaruh negatif dan signifikan terhadap return on asset.
\end{abstract}

Kata kunci: Current Ratio, Debt To Asset Ratio, Total Asset Turn Over, dan Return On Asset.

\begin{abstract}
This study aims to determine the effect of current ratio, debt to asset ratio, and total asset turn over on return on assets in Telecommunications Sub Sector Companies listed on the Indonesia Stock Exchange for the period 2013-2017. The data used is secondary data in the form of financial statements published by the Indonesia Stock Exchange through the site www.idx.co.id. The sample in this study were 4 out of 6 companies. The sampling technique is purposive sampling. The analytical method used is the determination of the estimation model,, classical assumption test, multiple linear regression equations, hypothesis testing. The results showed that current ratio and total asset turn over had a positive and significant effect on return on assets, while debt to asset ratio had a negative and significant effect on return on assets.
\end{abstract}

Keywords: : Current Ratio, Debt To Asset Ratio, Total Asset Turn Over, and Return On Asset 


\section{PENDAHULUAN}

Dalam beberapa tahun terakhir, industri telekomunikasi mengalami perkembangan yang sangat pesat. Meskipun kondisi perekonomian Indonesia yang menantang dan nilai tukar rupiah yang kian melemah, kebutuhan masyarakat terhadap produk telekomunikasi kian meningkat. Hal ini dapat dibuktikan dengan data publikasi Badan Pusat Statistik bahwa perkembangan PDB sektor informasi dan komunikasi tahun 2017 mengalami pertumbuhan sebesar $9,81 \%$ dari tahun sebelumnya, di mana pencapaian ini merupakan pertumbuhan tertinggi dibandingkan dengan sektor lainnya (Katadata,2018). Perkembangan industri telekomunikasi yang sangat pesat juga didukung oleh kemajuan teknologi informasi dan komunikasi serta adanya dukungan pemerintah, Direktorat Jenderal Sumber Daya dan Perangkat Pos dan Informatika (2018) menjelaskan bahwa pemerintah telah melakukan penataan ulang penggunaan spektrum frekuensi radio di Indonesia untuk mendukung teknologi Long Term Evolution (LTE). Teknologi ini merupakan teknologi telekomunikasi dengan akses data nirkabel tingkat tinggi yang berbasis pada jaringan GSM/EDGE dan Universal Mobile Telecommunications System (UMTS) dan High Speed Packet Access+ (HSPA+) sehingga mampu mendownload sampai dengan kecepatan 300 mbps dan upload 75 mbps. Sejak November 2014 sampai sekarang, sudah 6 spektrum frekuensi yang dialokasikan untuk teknologi 4G LTE yaitu $2.300 \mathrm{MHz}, 900 \mathrm{MHz}$, $1.800 \mathrm{MHz}, 450 \mathrm{MHz}, 800 \mathrm{MHz}$ dan 2.100 $\mathrm{MHz}$.

Sejak berlakunya Undang-Undang No. 36 Tahun 1999 Tentang Telekomunikasi, pada Pasal 10 Ayat 1 yang berisi bahwa dalam penyelenggaraan telekomunikasi dilarang melakukan kegiatan yang dapat mengakibatkan terjadinya praktek monopoli dan persaingan usaha tidak sehat di antara penyelenggara telekomunikasi.Industri telekomunikasi mengalami perubahan dalam pengelolaannya dari monopoli menjadi oligopoli. Perusahaan Sub Sektor Telekomunikasi yang pada awalnya hanya PT Telekomunikasi Indonesia sebagai badan pelaksana telekomunikasi untuk urusan dalam negeri dan PT Indosat sebagai badan pelaksana telekomunikasi internasional (Atsi, 2018). Kini telah berkembang menjadi 4 perusahaan Sub Sektor Telekomunikasi yang aktif dalam operator seluler dan telah terdaftar di Bursa Efek Indonesia yaitu Telekomunikasi Indonesia Tbk, Indosat Tbk, XL Axiata Tbk, dan Smartfren Telecom Tbk.Munculnya berbagai perusahaan Sub Sektor Telekomunikasi di Indonesia khususnya operator seluler menciptakan kondisi persaingan yang sangat ketat serta adanya kebijakan pemerintah di mana Kementerian Komunikasi dan Informatika (Kemkominfo) mewajibkan pengguna ponsel untuk mendaftarkan kartu SIM miliknya menggunakan nomor Kartu Keluarga (KK) dan Nomor Induk Kependudukan (NIK) KTP. Ketentuan ini akan berlaku mulai 31 Oktober 2017. Sementara batas akhir registrasi ulang kartu SIM yang divalidasi dengan NIK KTP dan nomor KK adalah 28 Februari 2018 (Damar, 2017). Menteri Komunikasi dan Informasi Rudiantara menjelaskan kebijakan registrasi ulang kartu prabayar membatasi 1 orang dengan Nomor Induk Kependudukan (NIK) e-KTP hanya boleh memiliki 3 kartu SIM. Bagi masyarakat yang memiliki usaha, maka nomor keempat harus didaftarkan di gerai milik operator agar tercatat dengan jelas (Saputri,2017).

Dengan adanya pendaftaran kartu SIM wajib dengan NIK dan KK serta pembatasan satu orang memiliki kartu SIM maksimal 3 (tiga), hal ini akan berdampak semakin terbatasnya pelanggan untuk menggunakan provider lain. Tentunya dengan munculnya berbagai perusahaan Sub Sektor Telekomunikasi serta adanya kebijakan pemerintah mengenai pembatasan kartu SIM, perusahaan dituntut mencari strategi yang efektif untuk dapat bertahan, untuk dapat mengatasi kebijakan pemerintah dan untuk dapat memenangi persaingan antar perusahaan sub sektor telekomunikasi.Suatu perusahaan didirikan mempunyai beberapa tujuan yang ingin dicapai dalam kegiatan operasionalnya yaitu perusahaan menginginkan modal yang telah ditanamkan dalam bentuk aset pada perusahaan kembali dengan cepat, selain itu perusahaan menginginkan keuntungan yang optimal dari hasil kegiatan usaha yang dijalankan. Agar tujuan perusahaan dapat tercapai, kegiatan usaha yang dijalankan perusahaan harus dipantau perkembangannya baik dengan laporan keuangan dalam suatu periode tertentu. Laporan keuangan yang 
dibuat tentunya harus sesuai dengan kaidah yang berlaku sehingga dapat diketahui kondisi dan posisi keuangan perusahaan. Laporan keuangan tentunya harus dilakukan analisis, sehingga laporan keuangan yang telah di analisis dapat dipahami dan dimengerti bagi orang yang memiliki wewenang atau berkepentingan di perusahaan sehingga laporan keuangan dapat digunakan sebagai acuan dalam pengambilan keputusan perusahaan (Kasmir, 2015 hal. 2-4).

Untuk mengambil keputusan perusahaan yang semakin baik bagi orang yang memiliki kepentingan di perusahaan, rasio keuangan dapat digunakan untuk mengukur kinerja keuangan salah satunya dapat menggunakan return on asset. Return on asset merupakan salah satu rasio dari rasio profitabilitas yang dapat mengukur seberapa besar jumlah laba bersih yang akan dihasilkan dari setiap dana yang tertanam dalam total aset. Semakin tinggi hasil pengembalian atas aset berarti semakin tinggi pula jumlah laba bersih yang dihasilkan dari setiap rupiah dana yang tertanam dalam total aset. Sebaliknya, semakin rendah hasil pengembalian atas aset berarti semakin rendah pula jumlah laba bersih yang dihasilkan dari setiap rupiah dana yang tertanam dalam total aset (Hery, 2015 hal. 193).

Beberapa penelitian mengenai pengaruh current ratio, debt to asset ratio, dan total asset turn over terhadap return on asset masih mengalami perbedaan hasil penelitian. Berdasarkan hasil penelitian terdahulu masih menunjukkan research gap untuk variabel yang mempengaruhi return on asset. Perbedaan penelitian tentang pengaruh current ratio terhadap return on asset yaitu antara penelitian Utama dan Muid (2014), Mahardika dan Marbun (2016), serta Suyono dan Gani (2018) yang menunjukkan bahwa current ratio berpengaruh positif terhadap return on asset, sementara penelitian yang dilakukan oleh Angela dkk. (2015) menunjukkan bahwa current ratio berpengaruh negatif terhadap return on asset. Kemudian perbedaan penelitian tentang pengaruh debt to asset ratio terhadap return on asset yaitu antara penelitian Barus dan Leliani (2013), dan Supardi dkk. (2016) menunjukkan bahwa debt to asset ratio berpengaruh negatif terhadap return on asset, sementara penelitian yang dilakukan oleh Angela dkk. (2015) bahwa debt to asset ratio berpengaruh positif terhadap return on asset.
Selanjutnya perbedaan penelitian tentang pengaruh total asset turn over terhadap return on asset yaitu antara penelitian Barus dan Leliani (2013), Pranata dkk. (2014), Angela dkk. (2015), Supardi dkk. (2016) serta Suyono dan Gani (2018) menunjukkan bahwa totalasset turn over berpengaruh positif terhadap return on asset, sementara penelitian yang dilakukan oleh Noormuliyaningsih dan Swandari (2016) menunjukkan bahwa totalasset turn over berpengaruh negatif terhadap return on asset. Berdasarkan uraian dari latar belakang masalah, maka dapat ditentukan rumusan masalah penelitian ini adalah apakah current ratio, debt to asset ratio, dan total asset turn over berpengaruh terhadap return on asset perusahaan Sub Sektor Telekomunikasi. Sedangkan tujuan penelitian adalah untuk mengetahui pengaruh current ratio, debt to asset ratio, dan total asset turn over terhadap return on asset perusahaan Sub Sektor Telekomunikasi.

\section{METODE PENELITIAN}

Jenis penelitian ini menggunakan permasalahan asosiatif dengan pendekatan kuantitatif. Kemudian dalam penelitian ini data yang digunakan adalah data sekunder. Adapun populasi yang digunakan dalam penelitian ini adalah perusahaan Sub Sektor Telekomunikasi yang terdaftar di Bursa Efek Indonesia (BEI) pada periode 2013-2017. Dalam penentuan sampel menggunakan non probability sampling dengan teknik purposive sampling di mana pada teknik ini dalam penentuan sampel dilakukan dengan adanya suatu pertimbangan tertentu atau adanya suatu kriteria yang ditentukan, sehingga diperoleh 4 perusahaan yang dijadikan sampel. Selain itu, teknik pengumpulan data menggunakan teknik dokumentasi yang didasarkan pada laporan keuangan perusahaan Sub Sektor Telekomunikasi yang dipublikasikan oleh Bursa Efek Indonesia melalui www.idx.co.id pada periode 2013-2017.

Teknik analisis data menggunakan analisis regresi linear berganda data panel. Adapun tahapan dalam menganalisis regresi linear berganda data panel terdiri dari penentuan model estimasi, uji asumsi klasik, koefisien determinasi, dan uji hipotesis. Dalam penentuan model estimasi antara common effect model, fixed effect model, dan random 
effect model digunakan uji chow, uji hausman dan uji lagrange multiplier. Uji chow bertujuan untuk mengetahui perbandingan model estimasi yang terbaik antara common effect model atau fixed effect model, uji hausman bertujuan untuk mengetahui perbandingan model estimasi yang terbaik antara fixed effect model atau random effect model, sedangkan uji lagrange multiplier bertujuan untuk mengetahui perbandingan model estimasi yang terbaik antara random effect model atau commoneffect model.

Selanjutnya adalah pengujian asumsi klasik yang terdiri dari uji normalitas, multikolinearitas, heteroskedastisitas, dan autokorelasi. Uji normalitas bertujuan untuk menguji apakah dalam model regresi variabel pengganggu atau residual mempunyai distribusi normal, uji multikolinearitas bertujuan untuk menguji apakah dalam model regresi ditemukan adanya korelasi yang tinggi atau sempurna antar variabel independen, uji heterodeksitas bertujuan untuk mengetahui apakah variance dari residual data satu observasi ke observasi lainnya berbeda ataukah tetap, sedangkan uji autokorelasi bertujuan menguji apakah dalam suatu model regresi linear ada korelasi antarkesalahan penggangu (residual) pada periode $t$ dengan kesalahan pada periode t-1 (sebelumnya).

Kemudian dilakukan pengujian regresi linear berganda dengan data panel yang mengacu pada hasil penentuan model estimasi yang terbaik. Pengujian ini bertujuan untuk mengetahui arah pengaruh dan signifikan dari current ratio, debt to asset ratio, dan total asset turn over terhadap return on asset dengan melihat persamaan pada regresi linear berganda dan uji hipotesis menggunakan uji statistik t.

\section{HASIL DAN PEMBAHASAN}

Berikut adalah hasil penentuan medel estimasi. Langkah pertama menggunakan uji chow dengan hasil sebagai berikut:

Tabel 1. Penentuan Model Estimasi

\begin{tabular}{|l|l|}
\hline \multicolumn{1}{|c|}{ Keterangan } & Hasil \\
\hline $\begin{array}{l}\text { Cross-section Chi-square } \\
\text { Probability }\end{array}$ & 0,0385 \\
\hline $\begin{array}{l}\text { Cross-section One-sided } \\
\text { Breusch-Pagan }\end{array}$ & 0,4112 \\
\hline
\end{tabular}

Sumber: data diolah (2019)
Tabel 1 menunjukkan bahwa dalam uji chow diketahui nilai Cross-section F Statistic sebesar 0,0385 lebih kecil dari 0,05 sehingga uji chow menghasilkan model estimasi yang terbaik yaitu common effect model. Maka pengujian selanjutnya dilanjutkan dengan uji lagrange multiplier. Selanjutnya berdasarkan tabel 1 untuk uji lagrange multiplier diketahui nilai Cross-section One-sided Breusch-Pagan sebesar 0,4112 lebih besar dari 0,05 sehingga uji lagrange multiplier menghasilkan model estimasi yang terbaik yaitu common effect model. Oleh karena itu, pada pengujian selanjutnya akan menggunakan model estimasi common effect model. Dalam pengujian asumsi klasik terdiri dari uji normalitas, multikolinearitas, heteroskedastisitas, dan autokorelasi. Berikut hasil keempat jenis dari asumsi klasik tersebut:

Tabel 2. Uji Asumsi Klasik

\begin{tabular}{|l|l|}
\hline \multicolumn{1}{|c|}{ Keterangan } & Hasil \\
\hline Jarque-Bera Probability & 0,7378 \\
\hline Nilai VIF CR & 3,7050 \\
\hline Nilai VIF DAR & 3,2769 \\
\hline Nilai VIF TATO & 2,1020 \\
\hline $\begin{array}{l}\text { Nilai Probabilitas Uji } \\
\text { Glejser CR }\end{array}$ & 0,2509 \\
\hline $\begin{array}{l}\text { Nilai Probabilitas Uji } \\
\text { Glejser DAR }\end{array}$ & 0,2710 \\
\hline $\begin{array}{l}\text { Nilai Probabilitas Uji } \\
\text { Glejser TATO }\end{array}$ & 0,0930 \\
\hline Nilai Durbin-Watson & 1,7523 \\
\hline
\end{tabular}

Sumber: data diolah (2019)

Berdasarkan tabel 2 diketahui bahwa nilai probabilita uji jarque-bera sebesar 0,7378 lebih besar dari 0,05 maka data berdistribusi normal. Kemudian nilai Variance Inflation Factor CR, DAR, dan TATO masing-masing sebesar 3,7050, 3,2769, dan 2,1020 berada dibawah 10 maka tidak ada masalah multikolinearitas. Selanjutnya, dalam uji glejser diketahui nilai probabilita CR, DAR, dan TATO masingmasing sebesar sebesar 0,2509, 0,2710, dan 0,0930 lebih besar dari 0,05 maka tidak ada heteroskedastisitas. Selain itu, nilai DurbinWatson (DW) sebesar 1,7523 berada diantara nilai dU sebesar 1,6763 dan nilai 4-dU sebesar 2,324 dengan demikian dapat dikatakan bahwa data dalam penelitian ini tidak ada autokorelasi.

Analisis regresi linear berganda dengan data panel mengikuti pada hasil penentuan model 
estimasi. Dalam penentuan model estimasi didapatkan hasil common effect model yang terbaik dalam penelitian. Adapun hasil regresi linear berganda dengan menggunakan common effect model sebagai berikut:

Tabel 3. Hasil Regresi Linear Berganda

\begin{tabular}{|c|c|c|}
\hline \multirow{2}{*}{ Keterangan } & \multicolumn{2}{|c|}{ Hasil } \\
\cline { 2 - 3 } & Koefisien & Prob. \\
\hline CR & 0,0884 & 0,0236 \\
\hline DAR & $-0,1849$ & 0,0245 \\
\hline TATO & 0,2779 & 0,0000 \\
\hline Adjusted $R^{2}$ & 0,9325 & - \\
\hline
\end{tabular}

Sumber: data diolah (2019)

Berdasarkan hasil regresi linear berganda pada tabel 1, diketahui bahwa current ratio berpengaruh positif terhadap return on asset dengan nilai koefisien sebesar 0,0884. Kemudian berdasarkan hasil perhitungan uji statistik t, menunjukkan bahwa nilai probabilita sebesar 0,0236 lebih kecil dari 0,05 maka dapat dikatakan bahwa current ratio berpengaruh signifikan terhadap return on asset. Sehingga current ratio berpengaruh positif dan signifikan terhadap return on asset. Hasil penelitian ini juga konsisten dengan hasil penelitian Utama dan Muid (2014), Mahardika dan Marbun (2016), serta Suyono dan Gani (2018) yang menemukan hasil bahwa current ratio berpengaruh positif dan signifikan terhadap return on asset. Namun tidak konsisten dengan hasil penelitian Angela dkk. (2015) yang menemukan hasil bahwa current ratio berpengaruh negatif dan signifikan terhadap return on asset.

Adanya pengaruh positif dan signifikan pada current ratio terhadap return on asset. Menjelaskan bahwa perusahaan Sub Sektor Telekomunikasi yang memiliki nilai current ratio tinggi maka akan meningkatkan nilai return on asset. Karena current ratio yang tinggi akan menjamin kemampuan dalam membayar hutang jangka pendek karena tingginya aktiva lancar yang tersedia di perusahaan. Komponen aktiva lancar meliputi kas, bank, surat-surat berharga, piutang, sediaan, biaya dibayar di muka, pendapatan yang masih harus diterima, pinjaman yang diberikan, dan aktiva lancar lainnya. Komponen aktiva lancar yang dapat dikonversi menjadi kas adalah persediaan (inventory) dan piutang dagang yang dapat menjadi sumber pendapatan bagi perusahaan. Sehingga tingginya distribusi aktiva lancar yang tersedia di perusahaaan dapat meningkatkan nilai return on asset.

Berd Berdasarkan hasil regresi linear berganda pada tabel 1 diketahui bahwa debt to asset ratio berpengaruh negatif terhadap return on asset dengan presentase sebesar $-0,1849$. Kemudian berdasarkan hasil perhitungan uji statistik $\mathrm{t}$ menunjukkan bahwa nilai probabilita sebesar 0,0245 lebih kecil dari 0,05 maka dapat dikatakan bahwa debt to asset ratio berpengaruh signifikan terhadap return on asset. Sehingga debt to asset ratio berpengaruh negatif dan signifikan terhadap return on asset. Hasil penelitian ini juga konsisten dengan hasil penelitian Barus dan Leliani (2013), dan Supardi dkk. (2016) bahwa debt to asset ratio berpengaruh negatif dan signifikan terhadap return on asset. Namun tidak konsisten dengan hasil penelitian Angela dkk. (2015) serta Utama dan Muid (2014) yang menemukan hasil bahwa debt to asset ratio berpengaruh negatif dan tidak signifikan terhadap return on asset.

Adanya pengaruh negatif dan signifikan pada debt to asset ratio terhadap return on asset. Menjelaskan bahwa perusahaan Sub Sektor Telekomunikasi yang memiliki nilai debt to asset ratio tinggi maka akan menurunkan nilai return on asset. Karena semakin tinggi debt to asset ratiomaka pendanaan dengan hutang semakin banyak sehingga semakin sulit bagi perusahaan Sub Sektor Telekomunikasi untuk memperoleh tambahan pinjaman karena dikhawatirkan perusahaan tidak mampu menutupi hutang-hutangnya dengan aktiva yang dimilikinya. Dengan tingginya total hutang dapat berpengaruh terhadap pengelolaan aktiva. Oleh karena itu akan berdampak pada perolehan laba yang akan diterima oleh perusahaan dan dapat menurunkan return on asset. Berdasarkan hasil regresi linear berganda pada tabel 1, diketahui bahwa total asset turn over berpengaruh positif terhadap return on asset dengan presentase sebesar 0,2779. Kemudian berdasarkan hasil perhitungan uji statistik t menunjukkan bahwa nilai probabilitas sebesar 0,0000 lebih kecil dari 0,05 maka dapat dikatakan bahwa total asset turn over berpengaruh signifikan terhadap return on asset. Sehingga total asset turn over berpengaruh positif dan signifikan terhadap return on asset. Hasil penelitian ini 
juga konsisten dengan hasil penelitian Barus dan Leliani (2013), Pranata dkk. (2014), Angela dkk. (2015), Supardi dkk. (2016) serta Suyono dan Gani (2018) bahwa total asset turn over berpengaruh positif dan signifikan terhadap return on asset. Namun tidak konsisten dengan hasil penelitian Noormuliyaningsih dan Swandari (2016) yang menemukan hasil bahwa total asset berpengaruh negativel dan tidak signifikan terhadap return on asset.

Adanya pengaruh positif dan signifikan pada total asset turn over terhadap return on asset. Menjelaskan bahwa perusahaan Sub Sektor Telekomunikasi yang memiliki nilai total asset turn over tinggi maka akan meningkatkan nilai return on asset. Karena semakin tinggi total asset turn over maka dapat dikatakan bahwa

\section{KESIMPULAN}

Berdasarkan hasil penelitian dan pembahasan maka kesimpulan dari hasil penelitian ini adalah current ratio dan total asset turn over berpengaruh positif dan signifikan terhadap return on asset perusahaan Sub Sektor Telekomunikasi yang terdaftar di Bursa Efek Indonesia. Sedangkan debt to asset ratio berpengaruh negatif dan signifikan terhadap return on asset perusahaan Sub Sektor Telekomunikasi yang terdaftar di Bursa Efek Indonesia.

\section{DAFTAR PUSTAKA}

Angela, M., Widayanti, R., \& Colline, F. (2015). Pengaruh Current Ratio, Total Asset Turnover, Dan Debt To Total Asset Terhadap Return On Asset Pada Perusahaan Lq45 Di Bursa Efek Indonesia Periode 2011-2013. Jurnal Ilmiah Manajemen Bisnis, 15(1).

Asosiasi Peyelenggara Telekomunikasi Seluruh Indonesia. (2018). Tentang Kami. Diperoleh dari URL: http://www.atsi.or.id/tentang-kami/ diakses 22 Nopember 2018

Barus, A. C., \& Leliani. (2013). Analisis Faktor-Faktor Yang Mempengaruhi Profitabilitas Pada Perusahaan Manufaktur Yang Terdaftar Di Bursa Efek Indonesia. Jurnal Wira Ekonomi Mikroskil, 3(2).

Damar, Agustinus Mario. (2017). Alasan Kemkominfo Wajibkan Registrasi Kartu kinerja perusahaan Sub Sektor Telekomunikasi baik, karena perusahaan efisien dalam menggunakan aset untuk menghasilkan penjualan. Sehingga dengan kinerja perusahaan yang baik akan tercerminkan ke dalam nilai return on asset yang baik pula.

Berdasarkan hasil penelitian dan pembahasan maka kesimpulan dari hasil penelitian ini adalah current ratio dan total asset turn over berpengaruh positif dan signifikan terhadap return on asset perusahaan Sub Sektor Telekomunikasi yang terdaftar di Bursa Efek Indonesia. Sedangkan debt to asset ratio berpengaruh negatif dan signifikan terhadap return on asset perusahaan Sub Sektor Telekomunikasi yang terdaftar di Bursa Efek Indonesia.

SIM Pakai KTP dan KK [Rilis Pers]. Diperoleh dari URL: https://www.liputan6.com/tekno/read/31 27088/alasan-kemkominfo-wajibkanregistrasi-kartu-sim-pakai-ktp-dan-kk diakses 22 Nopember 2018.

Direktorat Jenderal Sumber Daya dan Perangkat Pos dan Informatika. 2018. Data Statistik Direktorat Jenderal Sumber Daya dan Perangkat Pos dan Informatika Semester-2 Tahun 2017. Bogor: IPB Press.

Hery. (2015). Analisis Kinerja Manajemen. Jakarta: PT Grasindo.

Hery. (2015). Pengantar Akuntansi Comprehensive Edition. Jakarta: PT Grasindo.

Kasmir. (2015). Analisis Laporan Keuangan (1 ed.). Jakarta: Rajawali Pers.

Katadata. (2018). Sektor Informasi dan Komunikasi Mencatat Pertumbuhan Tertinggi [Rilis Pers]. Diperoleh dari URL: https://databoks.katadata.co.id/datapubli sh/2018/02/06/2017-sektor-informasidan-komunikasi-mencatat-pertumbuhantertinggi diakses 22 Nopember 2018.

Mahardhika, P., \& Marbun, D. (2016). Pengaruh Current Ratio Dan Debt To Equity Ratio Terhadap Return On Assets. Widyakala, 3, hal. 23-28.

Noormuliyaningsih, Tri dan Swandari, Fifi. (2016). Pengaruh Rasio Aktivitas Dan Rasio Leverage Terhadap Tingkat Profitabilitas Jurnal Wawasan 
Manajemen, Vol. 4, Nomor 1, Februari 2016

Pranata, D., Hidayat, R. R., \& Nuzula, N. F. (2014). Pengaruh Total Asset Turnover, Non Performing Loan, Dan Net Profit Margin Terhadap Return On Asset (Studi Pada Bank Umum Swasta Devisa Yang Terdaftar Di Bank Indonesia Tahun 2010-2012). Jurnal Administrasi Bisnis, 11(1).

Saputri, Maya. (2017). Kebijakan Registrasi Simcard Hanya Bolehkan 1 NIK Punya 3 Kartu [Rilis Pers]. Diperoleh dari URL: $\quad$ https://tirto.id/kebijakanregistrasi-simcard-hanya-bolehkan-1nik-punya-3-kartu-cyUN. diakses 22 Nopember 2018.

Supardi, H., Suratno, H., \& Suyanto. (2016). Pengaruh Current Ratio, Debt To Asset Ratio, Total Asset Turnover Dan Inflasi Terhadap Return On Asset. Jurnal Ilmiah Akuntansi Fakultas Ekonomi, 2(2), hal. 16-27.

Suyono, \& Gani, E. A. (2018). Analysis Of Liquidity Ratio, Activity Ratio, Working Capital Ratio, And Solvency Ratio On The Profitability Of Telecommunication Companies Listed On BEI (Period 20112016). Procuratio, 6(1).

Utama, A. C., \& Muid, A. (2014). Pengaruh Current Ratio, Debt Equity Ratio, Debt Asset Ratio, Dan Perputaran Modal Kerja Terhadap Return On Asset Pada Perusahaan Manufaktur Yang Terdaftar Di Bursa Efek Indonesia Tahun 20102012. Diponegoro Journal of Accounting, 3(2), hal. 1-13.

Warrad, L., \& Omari, R. A. (2015). The Impact Of Turnover Ratios On Jordanian Services Sectors' Performance. Journal of Modern Accounting and Auditing, 11(2), hal. 7785. 